\title{
HISTOLOGY OF THE TRACHEA AND LUNG OF Siphonops annulatus (AMPHIBIA, GYMNOPHIONA)
}

\author{
KUEHNE, B. ${ }^{1}$ and JUNQUEIRA, L. C. U. ${ }^{2}$ \\ ${ }^{1}$ Departamento de Ciências Biológicas, Faculdade de Farmácia e Odontologia de Alfenas, MG, Brazil \\ ${ }^{2}$ Laboratório de Biologia Celular, Departamento de Patologia, Faculdade de Medicina, Universidade de São Paulo, \\ SP, Brazil \\ Correspondence to: Luiz Carlos Uchoa Junqueira, Santiago 99, CEP 37701-373, Poços de Caldas, MG, Brazil \\ Received November 9, 1998 - Accepted January 7, 1999 - Distributed February 28, 2000
}

(With 10 figures)

\begin{abstract}
The structure of the trachea and lung of Siphonops annulatus was studied in ten specimens of routinely fed animals. The trachea is constituted mainly by incomplete cartilage rings lined by a respiratory epithelium (ciliated and mucous cells) with variable morphology according to the region observed. A rich vascularization of this organ suggests its participation in blood-air gas exchange. The right lung in this species is developed and the left one is atrophied. This organ is constituted mainly by longitudinal septa formed by connective tissue, smooth muscle cells and blood capillaries. These structures are covered by pneumocytes of one type only, which present cytoplasmic particles that have been related with surfactant activity described in the lung of Gymnophiona.
\end{abstract}

Key words: Gymnophiona, Siphonops, trachea, lung, structure.

\section{RESUMO}

\section{Histologia da traquéia e do pulmão de Siphonops annulatus (Amphibia, Gymnophiona)}

As estruturas da traquéia e do pulmão desse animal foram estudadas em dez exemplares, rotineiramente alimentados. A traquéia é constituída por anéis cartilaginosos incompletos, revestidos internamente por epitélio respiratório (células ciliadas e mucosas), que apresentam características variáveis, de acordo com a região estudada. A rica vascularização sugere que este órgão participe na troca gasosa ar-sangue. Nesta espécie, o pulmão esquerdo é atrofiado e o direito desenvolvido. Este órgão é formado, basicamente, por pregas longitudinais, constituídas por tecido conjuntivo, músculo liso e capilares sangüíneos, que se apresentam cobertos por pneumócitos de um só tipo. Essas células apresentam partículas citoplasmáticas, as quais já foram relacionadas com a produção de substâncias surfactantes no pulmão de Gymnophiona.

Palavras-chave: Gymnophiona, Siphonops, traquéia, pulmão, estrutura.

\section{INTRODUCTION}

Siphonops annulatus (Mikan, 1828) is a Gymnophiona that has an annulated body and is adapted to terrestrial fossorial life. It is the most widely distributed caecilian in South America, where it lives in humid and semiarid areas. It presents a copulatory organ and produces eggs with shell that develop without close contact with water. Because of their distribution and the environment they live in the Gymnophiona constitute one of the most unknown groups of terrestrial vertebrates
(Duellman \& Trueb, 1986). In this paper we present the histological structure of their trachea and lung.

The pertinent literature on the respiratory system of the amphibians is presented in Marcus (1937) review up to the decade of 1930. Recently its structure and histochemistry was reviewed in the excellent paper by Goniakowska-Witalinska (1995). The histology of the extrapulmonary airways of the amphibia has hardly been studied and was recently reviewed by Pastor \& Pascual (1995). 
Here we present the results obtained by analysing the structure of the trachea and lungs of Siphonops annulatus using 1 and $2 \mu \mathrm{m}$ sections of resin embedded material that permits a better analysis and understanding of the function of the cells and tissues studied (Junqueira, 1995).

\section{MATERIAL AND METHODS}

Ten adult specimens of Siphonops annulatus (Mikan, 1820) were used. Their tissues were fixed in $4 \%$ paraformaldeyde dissolved in $0,1 \mathrm{M}$ phosphate buffered saline, and embedded in a hydrophilic resin (Technovit 7100). One and two $\mu \mathrm{m}$ sections were stained with toluidin blue and fuchsin. Alternatively sections were stained with a variant of a Romanowski stain for hemopoetic tissues described by Rosenfeld (1947). To study the distribution of neutral and acid polyssaccharides associated to proteins, the periodic acid Schiff (PAS) and Alcian Blue methods were applied according to Bancroft \& Stevens (1990). The use of transverse and longitudinal sections was important for a better understanding of the organs studied.

\section{RESULTS}

\section{The Trachea}

This organ begins in the mouth and ends near the heart where it bifurcates. It is a thin (average $1,5 \mathrm{~mm}$ diameter) tubular structure whose framework consists initially by superimposed incomplete rings of hyaline cartilage covered with loose connective tissue. These rings gradually become segmented in the caudal region (Figs. 1A and $1 \mathrm{~B})$. Its inner lining is formed by a layer of epithelial tissue, whose aspect varies with its position in the organ. In the region that covers the cartilage this layer is formed by flattened or cubic cells that can present few short cilia interspersed with cubic cells containing small PAS positive granules in its apex (Figs. 2 and 3). In the portion covering the connective tissue, and consequently without cartilage, the epitelial cells are prismatic and present a well developed and conspicuous ciliated border (Fig. 2). Typical mucous goblet cells are frequently but not always interspersed among the ciliated cells. Many blood capillaries appear in this region below the epithelial layer (Fig. 3).

\section{The Lung}

This organ begins at the bifurcation of the trachea. Its left branch is short aproximately $10 \%$ of the right branch. The following description is of the right lung. It is a red long thin tube (diameter average $2 \mathrm{~mm}$ ) situated between the stomach and the liver and ending as a blind sac at the level of the lower third of the liver. It is bound to the dorsal wall by a mesopneumonium. This structure presents two layers of mesothelial cells separated by connective tissue and scarce blood and lymph vessels (Fig. 4). Its interior is divided by longitudinaly disposed septa that assume a radial disposition. These septa usually present a dilation in their innermost regions thus limiting a central, incomplete tube-like structure called Lungenbronchus by Marcus (1937). (Fig. 6A.)

These septa divide the lung in a series of cavities some of which can assume the locally the aspect of a closed structure. Longitudinal sections of these organs, however, show that all cavities intercomunicate. The Lungenbronchus tends to be a more continuous structure in the cranial region of the lung (Fig. 6A), but, due to a reduction in the amount of septal dilations, it assumes a more irregular aspect as we progress caudally in this organ (Fig. 6B).

These dilations can be the result of the local presence of large blood vessels or a cartilaginous structure or an aggregate of smooth muscle cells (Figs. 7 and 8). Two of the vascular dilations are disposed in opposite positions containing a large artery at one side and a vein, at the other (Fig. 6B). These large vessels are present practically in the total extent of this organ. The study of longitudinal sections shows that the cartilage and the smooth muscle aggregates form elongated structures disposed in cranio-caudal direction. Both muscular and cartilagenous aggregates decrease gradually in size and quantity in a cranio-caudal direction.

The epithelial layer covering the arterial dilation is formed by conspicuous ciliated cells frequently interspersed with mucous goblet cells (Fig. 7). The other dilations including those produced by the large vein are rarely covered with ciliated cells, but can present a continuous layer of cubic cells or an irregular row of capillaries cut transverselly and covered with pneumocytes (Fig. 8). 

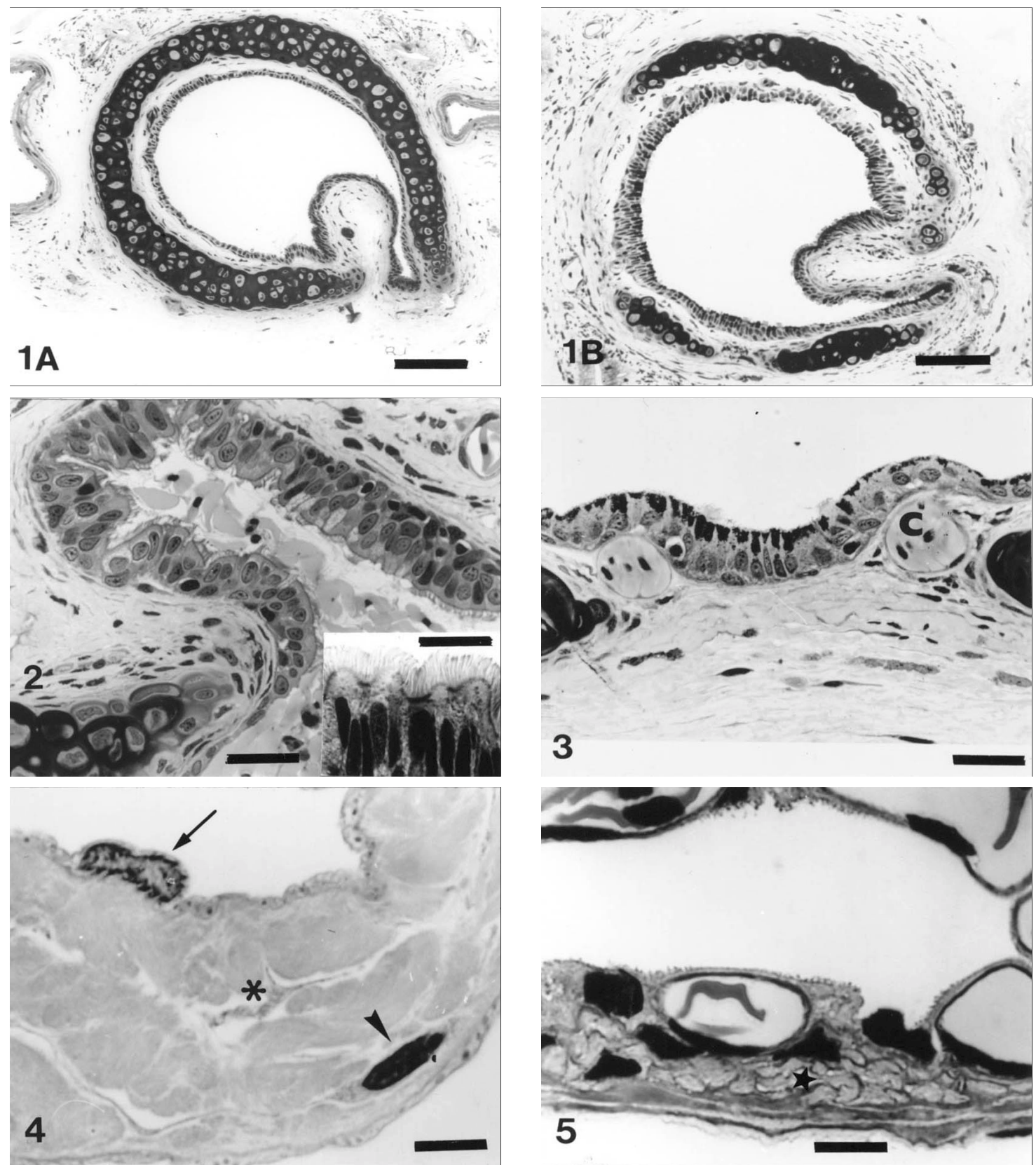

Figs. 1A and 1B - Transverse section of trachea. Its epithellial lining is separeted from the cartilage by loose connective tissue. Observe that the epithelial layer is thicker in the regions without cartilage. The cartilage ring is complete in the upper region -A- but is fragmented in the lower region -B-. Toluidin and fuchsin. Fig. 2 - Showing the thick epithelial layer covering the connective tissue and its thinning when over the cartilage. The epithelial lining is constituted by mucous cells and ciliated prismatic cells. Toluidin and fuchsin. When enlarged and stained with PAS and Rosenfeld, the ciliated and mucous cells are clearly visible. Fig. 3 - Longitudinal section of the trachea. Observe that the epithelial layer becomes thinner when covering the cartilage. The PAS method stains mucus present in reduced quantity when the cellular size is reduced. In C capillaries in close contact with the epithelial layer. PAS - Toluidin. Fig. 4 - Section of the mesopneumonium showing the collagen fibers, fibroblast nuclei, arrowhead and cell branches asterisks. Observe the flattened mesothelial cells with its nucleus arrow and citoplasm presenting numerous granular particles. Toluidin and fuchsin. Fig. $\mathbf{5}-$ Section of the pulmonary wall covered with mesothelial cells. The asterisk shows smooth muscle cells. Two bulging cappilaries are covered with pneumocytes whose nuclei are nested between them. Observe the microvilli in the pneumocytes surface. Toluidin and fuchsin. Bars of Figs. $1 \mathrm{~A}$ and $\mathrm{B}=200 \mu \mathrm{m}, 2=25$ and $10 \mu \mathrm{m}, 3=25 \mu \mathrm{m}, 4$ and $5=10 \mu \mathrm{m}$. 

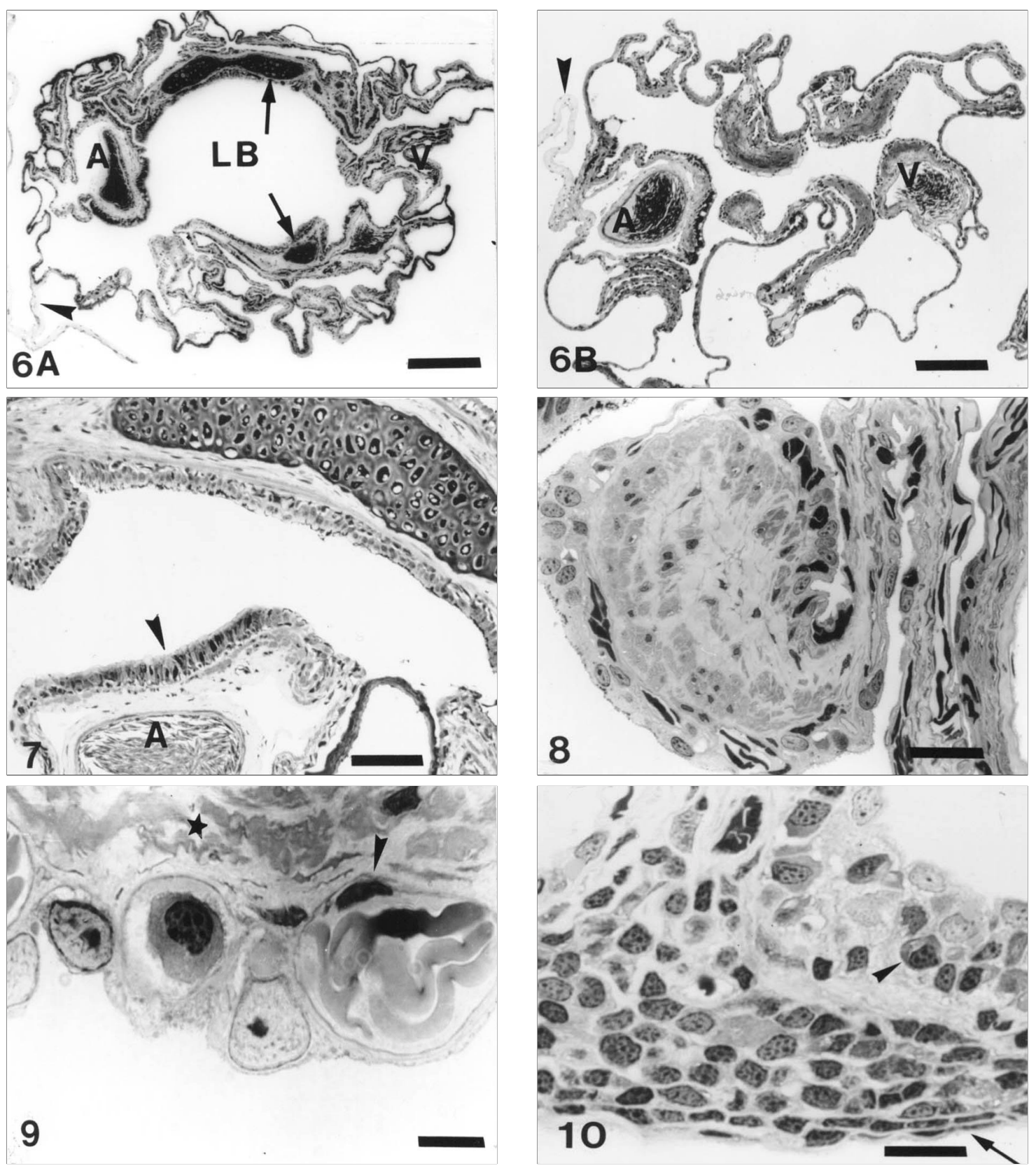

Figs. 6A and B - Transverse sections of the lung in its upper region A and lower B. In A the lungenbronchus (LB) is clearly delineated. The dilations of the septa contain mainly cartilagineous tissue (arrows). A and V show the opposing artery and vein. Arrowheads show the mesopneumonium. The diilations of the septa in the lower region B are constituted mainly by blood vessels and aggregates of smooth muscle. In this region the lungenbronchus is not clearly visible. Toluidin and fuchsin. Fig. 7 - Section of the lung in a lower region showing an artery A covered with a thick epithelial layer constituted by ciliated and mucous cells (arrowhead). In the upper region a segment of cartilage. PAS - Toluidin. Fig. 8 - Lung section showing at right the lung wall followed by a segment of a septum that binds the wall to a dilation containing smooth muscle cells and loose connective tissue. This structure is covered with cubic or flattened cells with scarce mucous granules and no cilliated cells. PAS - Toluidin. Fig. 9 - Section of the lung septum. With 2 transversely sectioned capillaries showing the endothelia cell nucleus (arrowhead) and two pneumocyte nuclei with their nucleoli. The pneumocytes with dark granules in their cytoplasm cover the capillaries. Asterisk in the smooth muscle layer. Toluidin and fuchsin. Fig. 10 - Lung wall with collection of lymphocytes. The arrowhead shows a plasmocyte. An arrow shows the mesothelium. The presence of aggregates of lymphocytes containing plasmocytes suggests that structures with immunological function described in mammals lungs may also occur in this animal. Toluidin and fuchsin. Bars of Figs. $6 \mathrm{~A}$ and $\mathrm{B}=0,5 \mu \mathrm{m}, 7$ and $8=200 \mu \mathrm{m}, 9=10 \mu \mathrm{m}$ and $10=25 \mu \mathrm{m}$. 
The outer surface of the lung, the equivalent of the visceral pleura, consists of an unicellular layer of flat mesothelial cells covering a layer of collagen fibers and smooth muscle cells. The inner surface is usually covered with transverselly sectioned capillaries covered with respiratory epithelial cells (pneumocytes) (Fig. 5).

The walls of the septa present a central axis of collagen fibers plus smooth muscle fibers, frequently covered with capillaries on both sides. These capillaries appear mostly in transverse sections, but aspects derived from oblique or longitudinal sections are not rare. They are covered with a thin layer of the pneumocytes cytoplasm.

The nuclei of these cells and parts of their cytoplasm are clearly seen in the space limited by two adjoining capillaries. Frequently two nuclei of adjoining cells are present in the same space (Fig. 9). When stained with the PAS method several pneumocytes present small, darkly stained granules in their cytoplasm. These cells are the only type of pneumocyte present in this species and they emit cytoplasmic projections that cover the neighboring capillaries forming with the endothelial cells the air-blood barrier that presents variable thickness ranging from 0,25 to $2 \mu \mathrm{m}$ with an average around $1,0 \mu \mathrm{m}$. The capillares have a variable diameter usually containing groups of erythrocytes that in this species measure $23 \times 18 \mu \mathrm{m}$. Some of these septa, however, present only one surface covered with capillaries while the other surface presents a layer of flattened or cubic cells whose cytoplasm can also contain small, PAS stained granules. Occasionaly aggregates of lymphoid cells were found at the wall of this organ (Fig. 10).

\section{DISCUSSION}

Scant information exists regarding the histology of the amphibian extrapulmonary airways (Pastor \& Pascual, 1995). In Gymnophiona a well defined trachea is present, but a detailed description of its structure could not be found. The presence in this organ of a well defined cartilagenous structure that can form an almost complete circle in its initial portion and that gradually becomes segmented in its caudal region speaks in favor of its importance in the maintenance of its patency to air. The fact that the tracheal epithelium which covers its cartilage is formed mainly by non ciliated cubic or flattened cells, contrasting with the prismatic ciliated epithelium in the other regions, might be explained by a locally better irrigation with consequent improved nutrition in this last region.

The close relation observed between the tracheal epithelium and its capillaries suggests a possible respiratory function of this organ, a possibility already proposed by Mendes (1941, 1945), who described in S. annulatus a specific tracheal artery derived from the pulmonary artery. Gymnophiona's lungs present a gross morphological diversity ranging from species with three lung lobules, two long lungs extending from the buccal cavity to the cloaca, one right developed lung and a left atrophied, or only a single short lung extended from the buccal cavity to the heart (Goniakowska-Witalinska, 1995). The situation present in S. annulatus (long right lung and short left lung) is common and was already described by Wiedersheim (1879). S. annulatus clearly presents only one type of pneumocyte and this situation with rare exceptions is widely accepted in all amphibians. (Goniakowska-Witalinska, 1995). In this species the pulmonary artery does not divide shortly after penetrating into the lung and is present in the entire length of this organ as an unique structure situated opposite to the vein. This disposition is present in Caudata, Gymnophiona and some Salentia (GoniakowskaWitalinska, 1995).

Contrary to the description of Marcus (1937) that ciliated cells do not occur in the lungs of Gymnophiona and are scarce in Afrocaecilia (Maina \& Maloly, 1988), our material shows that this type of epithelium occurs in quantity in the surface of the Lungenbronchus, a situation present in other Amphibia (Goniakowska-Witalinska, 1995).

Macrophages, cells frequently found in the alveolar wall and cavities of mammals, were not observed in S. annulatus, confirming their absence or scarcity described in amphibian lungs (Goniakowska-Witalinska, 1995).

In our material aggregates of cartilage were also observed with higher frequency in the initial portion of the lung, as described by Wiedersheim (1879) and Welsch (1981).

The blood-air barrier in S. annulatus is very thin and coincides with the observations in other Gymnophiona (Welsch, 1981; Pattle et al., 1977). 
These values for the blood-air barrier are variable as presented in Table 1 in the review of (Goniakowska-Witalinska, 1995).

The cytoplasm of the pneumocytes contains granules that probably correspond to the lamelated osmiophilic structures observed by other authors in the pneumocytes and considered to be related to the surfactant substance present in the lung. They were also found in Gymnophiona by Welsch (1981), Patle et al. (1977) and Maina \& Maloly (1988) and in our material in the non respiratory cubic epithelium present, covering the surface of some septa.

The microvilli that we observed on the surface of the pneumocytes were reported in some caudata (Goniakowska - Witalinska, 1995) and in two species of Gymnophiona by Welsch (1981) and are supposed to increase the cell surface, contributing to the distribution and preservation of mucus and surfactant substance bound to the lung surface.

Acknowledgments - The authors are grateful to Carlos Jared, who collected the animals.

\section{REFERENCES}

BANCROFT, J. B. \& STEVENS, A., 1990, Theory and practice of histological techniques. Churchil Livinsgstone, Edinburgh.

DUELlMAN, W. E. \& TRUEB, L., 1986, Biology of Amphibians. McGrawHill Book Co., New York.

GONIAKOWSKA-WITALINSKA, L., 1995, The histology and ultrastructure of the amphibian lung. In: L. M. Pastor (ed.), Histology, ultrastructure and immunohistochemistry of the respiratory organs in non mammalian vertabrates. Servicio de Publicationes, Universidade de Murcia, Murcia, pp. 77-112.

JUNQUEIRA, L. C. U., 1995, Histology revisited. Technical improvement promoted by the use of hydrophilic resin embbeding. Ciência e Cultura (Journal of the Brazilian Association for the Advancement of Science), 47: 92-95.
MAINA, J. N. \& MALOLY, G. M. O., 1988, A scanning and transmission electronmicroscopy study of the lung of a caecilian Boulengerula taitanus. J. Zool. Lond, 215: 739751.

MARCUS, H., 1937, Lungen. In: L. Boltz, E. Göppert, E. Kallius \& W. Lubosch (eds.), Handbuch der vergleichenden Anatomie der Wirbeltiere III. Urban und Schwartzenberg, Berlin.

MENDES, E. G., 1941, Sobre a respiração (esofágica, traqueal e cutânea) do Siphonops annulatus (Amphibia Gymnophiona). Bol. Fac. Filos. Ciênc. Let. Univ. S. Paulo, 5: 283-304.

MENDES, E. G., 1945, Contribuição para a fisiologia dos sistemas respiratório e circulatório de Siphonops annulatus (Amphibia - Gymnophiona). Bol. Fac. Filos. Ciênc. Let. Univ. S. Paulo, 9: 25-67.

MIKAN, J. C., 1820, Delectus Florae et Faunae Brasiliensis pl. 11, Vidabonae.

PASTOR, L. M. \& PASCUAL, A. G., 1995, The extrapulmonary airways in Amphibians. In: L. M. Pastor (ed.), Histology, Ultrastructure of the respiratory organs in non mammalian Vertebrates. Servicio de Publicationes. Universidade de Murcia, Murcia.

PATTLE, R. E., SHOCK, C., CREASLY, J. M. \& HUGHES, G. M., 1977, Surpellic films, lung surfactant, and their cellular origin in newt, caecilian and frog. J. Zool. Lond., 182: 125-136.

ROSENFELD, G., 1947, Corante pancrômico para hematologia e citologia clínica. Memórias do Instituto Butantã, 20: 320:334

WELSCH, U., 1981, Fine structural and enzyme histochemical study on the respiratory epithelium of the caecilian lungs and gills. A contribution to the understanding of the evolution of the respiratory epithelium. Arch. Histol. Jap., 44: 117-133.

WIEDERSHEIM, R., 1879, Die Anatomie der Gymnophionen. Fischer, Jena. 